\title{
AN OVERVIEW OF DETERMINATION OF MILK FAT: DEVELOPMENT, QUALITY CONTROL MEASURES, AND APPLICATION
}

\author{
Robert Kalaํ, Eva Samková1, Lenka Pecová1, \\ Oto Hanuš², Kęstutis Sekmokas ${ }^{3}$, Dalia Riaukienè ${ }^{3}$

\begin{abstract}
${ }^{1}$ Department of Food Biotechnologies and Agricultural Products Quality, Faculty of Agriculture, University of South Bohemia, Branišovská 1645/3la, 37005 České Budějovice, Czech Republic ${ }^{2}$ Dairy Research Institute, Ltd., Ke Dvoru 791/12a, 16000 Prague, Czech Republic ${ }^{3}$ SE "Pieno Tyrimai", Radvilu Dvaro str. 31, LT-48331 Kaunas, Lithuania
\end{abstract}

\begin{abstract}
KALA ROBERT, SAMKOVÁ EVA, PECOVÁ LENKA, HANUŠ OTO, SEKMOKAS KĘSTUTIS, RIAUKIENĖ DALIA. 2018. An Overview of Determination of Milk Fat: Development, Quality Control Measures, and Application. Acta Universitatis Agriculturae et Silviculturae Mendelianae Brunensis, 66(4): 1055-1064.

Milk fat content is an important indicator of milk quality because of nutritional and technological aspects of dairying. In this sense the milk fat determination is important practice procedure. The work goal was to do an effective overview and comparison of reference and routine methods of fat determination during their development. Nowadays, there exist a number of methods for determining milk fat content. Reference methods require accurate analysis in compliance with the International Standard ISO, whereas routine methods perform analysis using routine instrumental techniques for faster and cheaper results with acceptable accuracy. Quality control measures have a significant role for result determination reliability and they include internal quality controls, external quality controls, precision of evaluation, and blank samples. In conclusion, due to continuous development and improvement, routine methods will be used more often.
\end{abstract}

Keywords: milk fat, raw cow's milk, reference methods, routine methods

\section{INTRODUCTION}

Milk quality is an important factor in the dairy industry. One of the major factors of milk quality is composition, which affects the properties of the milk. Milk fat plays a significant role not only in the nutritional, physical, and chemical properties of milk, but also in the purchasability of milk (Upadhyay et al., 2018). Therefore, specific minimum standards of must be met in order for payment to be received by milk producers in the Czech Republic. These minimum standard values are, in accordance with standard CSN 57 0529, fat $\left(33 \mathrm{~g}^{-1} \mathrm{l}^{-1}\right)$, protein (28 $\left.\mathrm{g} \cdot \mathrm{l}^{-1}\right)$, and solid non-fat content $(8.5 \%)$ are required (CNI-Czech Normalization Institute, 1993).
Milk fat is the most variable component of ruminant milk (Samková et al., 2012). The fat content can vary from about $3 \%$ to $6 \%$, but typically in the range $3.5 \%$ to $4.7 \%$ (Lock and Bauman, 2011). Milk fat is composed of triacylglycerols (TAGs), diacylglycerols, phospholipids, free fatty acids, and cholesterol (Jensen and Newburg, 1995). The TAGs are the main component and represent about $97-98 \%$ of the total milk fat content (Vieitez et al., 2016).

The aim of our work is to describe and compare reference and routine methods used for analysis of milk fat. Furthermore, this overview describes quality control measures and applications for the mentioned methods. 


\section{Development of measurement methods}

Quality requirements in the food industry stimulate the development of analytical techniques capable of precise component quantification at a reasonable price of analysis (Kessler, 2013). Therefore, several analytical methods are reported for milk fat determination and quantification. In general, the efficiency of reference method results are usually more reliable, and also more expensive, than routine method results. For this reason, more routine methods for milk fat determination have been developed during the last hundred years.

The Butyrometric method is an operating method which can be used as a reference method for routine analytical procedures. The method was developed by the Swiss chemist and dairy-owner Niklaus Gerber (Gerber, 1891). In principle, proteins (mainly phospholipid envelopes of milk fat globules) are dissolved by sulfuric acid. Then, the addition of amyl-alcohol results in a sharp interface. Subsequently, the fat is quantitatively released and separated by centrifugation. Fat volume is read on the butyrometer scale which is calibrated to indicate the fat content in percentage by weight (ISO-International Standards Office, 1976). Under the conditions in the Czech Republic, this method is regulated by the COSMT-Czech Office for Standards, Metrology and Testing (2001) - CSN ISO 2446:2001. This method can be applied to raw milk, drinking milk (whole, semi-skimmed and skimmed milk), milk powder, cream and dairy products (cheese, yoghurt). In the USA and Canada the Babcock method is used with the same analytical principle as a modification of the Butyrometric method (CAES, 1894).

The Folch method (1957) is another method for fat content determination. In principle, lipid extraction is carried out with chloroform and methanol (e.g. 2:1). Then, the homogenate is filtered. The procedure enables extraction of lipid classes for subsequent fatty acid analysis (Budge et al., 2006). After extraction, transesterification (formation of fatty acid methyl esters) is carried out. This method is commonly used for marine products (Oftedal et al., 2014). However, the Folch method was used for milk fat determination of Weddell seal (Leptonychotes weddellii) (Wheatley et al., 2008) and bovine milk (Liu et al., 2016).

Similarly, the Bligh and Dyer method (1959) is used for extraction of fat. In principle, this method is also based on extraction using chloroform and methanol, but it was developed for lipid extraction of lean fish tissue (Iverson et al., 2001). After extraction, the homogenate is filtered and filtrate is transferred to a graduated cylinder. After allowing a few minutes for complete separation and clarification, the volume of the chloroform layer is recorded and the alcoholic layer removed by suction. Nevertheless, this method was used by Nascimento et al. (2017) for determination of fat content in commercial dried dairy products.

Maxwell et al. (1986) used a "dry-column method" for determination of fat. Firstly, the sample is dried by anhydrous sodium sulphate and diatomaceous earth (e.g. product Celite 545 by Supelco-Sigma-Aldrich Corp., USA). Subsequently, extraction is accomplished using a mixture of dichloromethane and methanol. The lipids may be isolated and simultaneously separated into neutral and polar fractions by a sequential elution procedure. Neutral lipids (without polar lipids) are eluted first with dichloromethane, followed by elution of polar lipids with the dichloromethane/methanol (9:1) mixture (Marmer and Maxwell, 1981). This method can be applied to raw milk, drinking milk (whole, semi-skimmed and skimmed milk) and buttermilk.

Supercritical fluid extraction (SFE) was investigated by Eller and King (1996) as an alternative to solvent-based extraction methods (Manganiello et al., 2000). The sample is weighed to the extraction thimble, previously loaded with $1 \mathrm{~g}$ of diatomaceous earth. a temperature of $100^{\circ} \mathrm{C}$ and sc- $\mathrm{CO}_{2}$ (supercritical carbon dioxide) fluid density of $0.60 \mathrm{mg} \cdot \mathrm{ml}^{-1}$ are used for extraction. Every fluid is characterized by a critical point, which is defined in terms of the critical temperature and critical pressure, thus $\mathrm{CO}_{2}$ is supercritical above 31.1 ${ }^{\circ} \mathrm{C}$ and $7.38 \mathrm{MPa}$ (Sahena et al., 2009). Sc- $\mathrm{CO}_{2}$ is removed exclusively nonpolar lipid material. Wolf et al. (2003) used SFE for analysis of milk infant formula powder whereas Astaire et al. (2003) applied method on buttermilk powders (with using microfiltration).

The Weibull-Berntrop gravimetric method involves Soxhlet extraction (García-Ayuso et al., 1999) and it is used for special dairy products-infant formula (ISO-Part 1, 2005), ice creams (ISO-Part 2, 2005) or special cases (ISO-Part 3, 2005). In principle, the method include hydrolysis (by hydrochloric acid) and extraction (by $n$-hexane). Next, the solvent was released in a rotary evaporator, followed by cooling in a dessicator and weighing. Tab. I summarizes individual methods.

\section{QUALITY CONTROL MEASURES}

The most important factors of correct analysis are sampling accuracy, sample manipulation, and quality control measures. Fat content is sensitive to sampling accuracy and may be influenced by this factor (Hanuš et al., 2008). Therefore, bulk or individual milk sampling is done according to the standards for sampling CSN EN ISO 707 (COSMT, 2009) to ensure accurate results.

The quality control measures serve as a mechanism for verifying the reliability of the results. Aside from compliance with the standard operating procedure (SOP), other measures include internal quality control (with quality control material), supervision of the working processes with audits (Glanzmann et al., 2017), external quality 
control-proficiency testing (Kaarls et al., 2017), two different methods for the same sample, precision of evaluation-repeatability and reproducibility (Verrezen et al., 2017), and blank samples. Basic statistical principles as well as rules of proficiency testing for reference and routine methods of raw milk fat determination were followed. These principles and rules are valid at the national and international level (milk laboratory networks) as many authors emphasized (Grappin, 1987, 1993; Hanuš et al., 1998; Leray, 2009a, 2009b, 2010).

Quality control material based on known composition is valuable in internal quality controls (Gargis et al., 2012). This material is comprised of control milk and positive and negative controls for different components (fat, protein, and others). Preparation of control milk starts with analysis of raw milk (primary and fast detection of composition and quality evaluation). Then, milk is properly mixed with preservatives (bronopol or sodium azide) and is dosed into plastic vials. Subsequently, milk can be refrigerated after dosing.

Under the Czech Republic conditions (Hanuš et al., 2014), the proficiency testing system is based on relevant standards-CSN 570530 (CNI, 1973), CSN 570536 (CNI, 1999) and CSN EN ISO/IEC 17025 (CNI, 2005). Proficiency testing not only reveals any errors in the results, but also provides the possibility for comparison with other participants who can identify potential problems, e.g. problems with calibration (Glanzmann et al., 2017). The procedure of proficiency testing is described in "Statistical methods for use in proficiency testing by inter-laboratory comparison" (ISO, 2010).

Before each analysis, samples are prepared by heating in a water bath, gently mixing, and then cooling to the room temperature. This procedure applies to particular samples designated in the calibration. To verify the accuracy of the results, it is also important to prepare a blank sample.

\section{REFERENCE METHODS}

Reference methods are thoroughly studied and defined measurement procedures. These methods are used to assess the reliability of other measurement procedures (Šprongl and Paulík, 2011).

Reference methods are linked to the primary methods of measurement defined as "methods having the highest metrological properties, whose operation can be completely described and understood, for which a complete uncertainty statement can be written down in terms of SI units" (Milton and Quinn, 2001). Primary methods used for chemical measurements include coulometry, gravimetry, titrimetry, and colligative methods (Quinn, 1997).

The ultimate precision method for determination of milk fat content is the Röse-Gottlieb method (Bogomolov et al., 2017), which replaced the Butyrometric method described above. The Mojonnier analytical method, which is essentially the same as the Röse-Gottlieb method with its similar reference extraction (Choi et al., 2015), is used in the USA and Canada for much the same reasons that the Röse-Gottlieb method is used over the Butyrometric method (Kleyn et al., 1988). In short, approximately $10 \mathrm{~g}$ (with precision of $0.0001 \mathrm{~g}$ ) of cow's milk is hydrolysed by ammonia. Subsequently, ethanol is added. Then fat is extracted with diethyl ether and petroleum ether (repeated liquid-liquid extraction, LLE). Fat content is weighed after evaporating the solvents (e.g. device SMT-Moplant series by Flohr Instrumenten and

I: Comparison of individual methods.

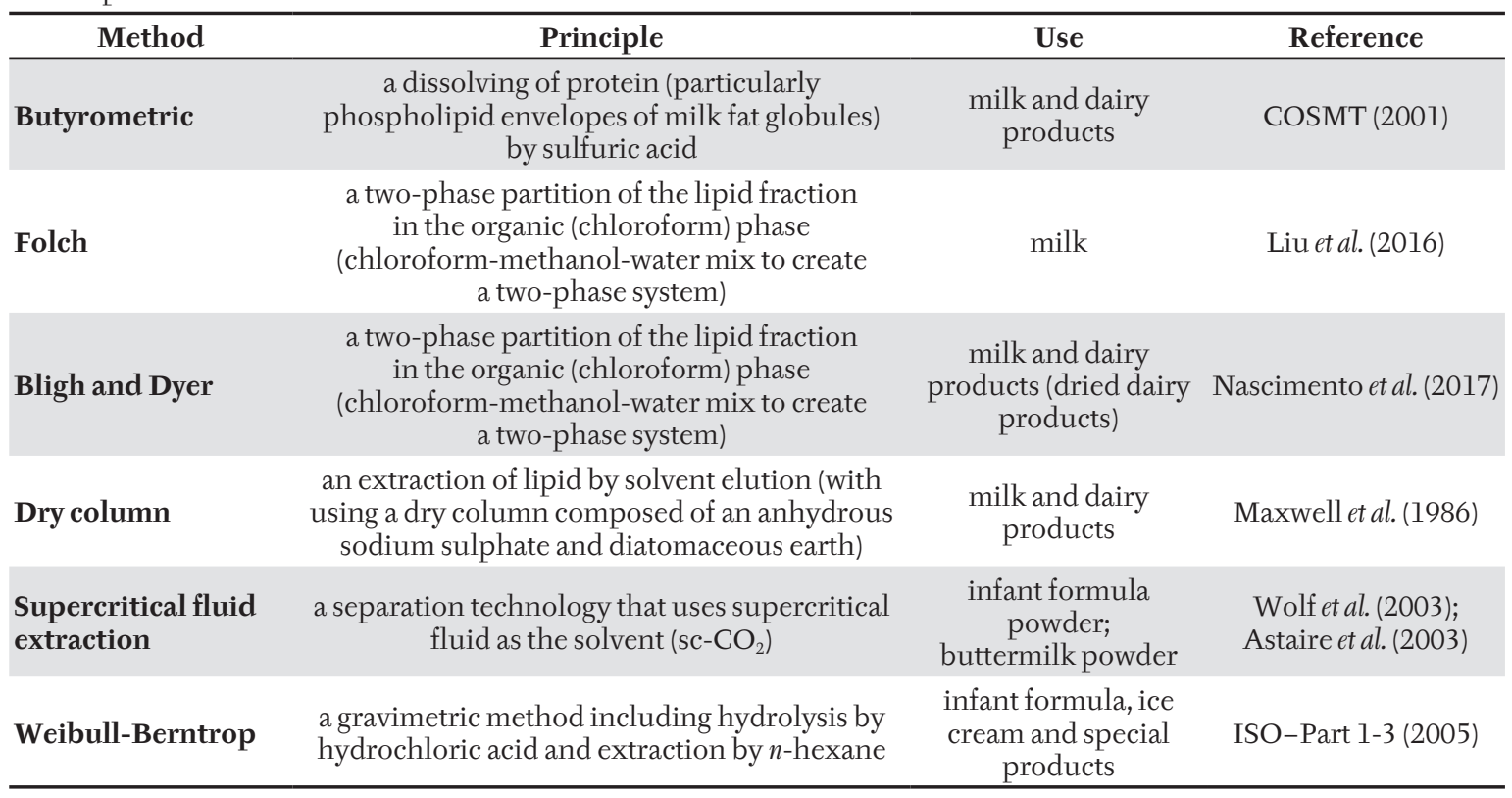

Sc- $\mathrm{CO}_{2}$-supercritical $\mathrm{CO}_{2}$ 
Apparatenbouw, Netherlands). Under the Czech Republic conditions, this method is regulated by CSN EN ISO 1211:2011 (COSMT, 2011). This method can be applied to raw milk and drinking milk (whole, semi-skimmed and skimmed milk).

In conclusion, reference methods (Tab. II) perform accurate analyses, which comply with the internal SOP according to the ISO International Standards. By contrast, reference methods have several disadvantages-time-consuming process of analyse and fewer analysed samples.

\section{ROUTINE METHODS}

Efficient routine analysis of milk fat is an important part of dairy production (Zhu et al., 2015). Nowadays, the aim is to develop fast and cost effective analytical methods that enable the identification of components with various physico-chemical properties in a single analytical run (Tankiewicz and Biziuk, 2018). Next, routine analyses are joined with routine implementation of performance-related tests for milk payment purposes under the Czech Republic conditions (Hanuš et al., 1998).

The main routine milk fat measurement principle from 1950 to 1980 for milk payment and milk recording laboratories in Europe was turbidimetry (nephelometry), (e.g. Electronic Milko Tester by Foss Electric, Denmark). Turbidimetric analysis was based on the observed correlation between fat content and the detected elimination of light dispersed by a milk sample at specific wavelengths (Ashworth, 1969). At present, this method is obsolete. Furthermore, the turbidimetric method is sensitive to the size variability of milk particles (e.g. milk fat globule), and, the testing of raw milk samples without prior treatment (by homogenization) is not very appropriate (Kucheryavskiy et al., 2014). This method can be primarily applied to drinking milk (whole, semi-skimmed and skimmed milk). On the other hand, Hanuš et al. (2014) described good results also with raw milk samples. The next routine method for determination of milk fat and other milk components is the ultrasound analytical procedure (Perlín, 2003).

Optical spectroscopy methods have the potential to replace or at least to complement some of the classical laboratory methods (El-Abassy et al., 2011). Spectroscopic methods of determination of fat are mainly based on the components absorption. The precondition is minimal to no scatter (Rinnan et al., 2009). The spectral ranges (Fig. 1) that are commonly used in spectrometry include: visible (VIS), short-wave infrared (SWIR), near-infrared (NIR), mid-infrared (MIR), long-wave infrared (LWIR), or thermal infrared (TIR) light (van der Meer, 2018).

The VIS light region (360-780 nm), where the scatter strongly dominates, is rarely used in quantitative milk analysis (Crofcheck et al., 2000). Cabassi et al. (2013) reported, that particularly in the region below $1100 \mathrm{~nm}$, the scatter strongly dominates over weak absorption. Nevertheless, Bogomolov et al. (2013) describes scatter-based quantitative analysis of fat in the raw milk using VIS and SWIR spectroscopy. According to these authors, difference of individual spectral elements of scatter (e.g. wavelength dependence) at different-sized milk fat globules are said to be sufficient for their quantitative analysis using formal multivariate modelling, e.g. partial least-squares (PLS) regression.

II: Comparison of individual reference methods.

\begin{tabular}{cccc}
\hline \multicolumn{1}{c}{ Method } & Principle & Use & Reference \\
\hline Mojonnier & $\begin{array}{c}\text { a gravimetric method } \rightarrow \text { separation the fat fraction (limited to } \\
\text { the lipophilic ether phase) from the rest of the milk sample }\end{array}$ & milk & Choi et al. (2015) \\
Röse-Gottlieb & $\begin{array}{c}\text { a gravimetric method including hydrolysis by ammonia and } \\
\text { extraction by diethyl ether and petroleum ether (repeated LLE) }\end{array}$ & milk & COSMT (2011) \\
\hline
\end{tabular}

LLE-liquid-liquid extraction

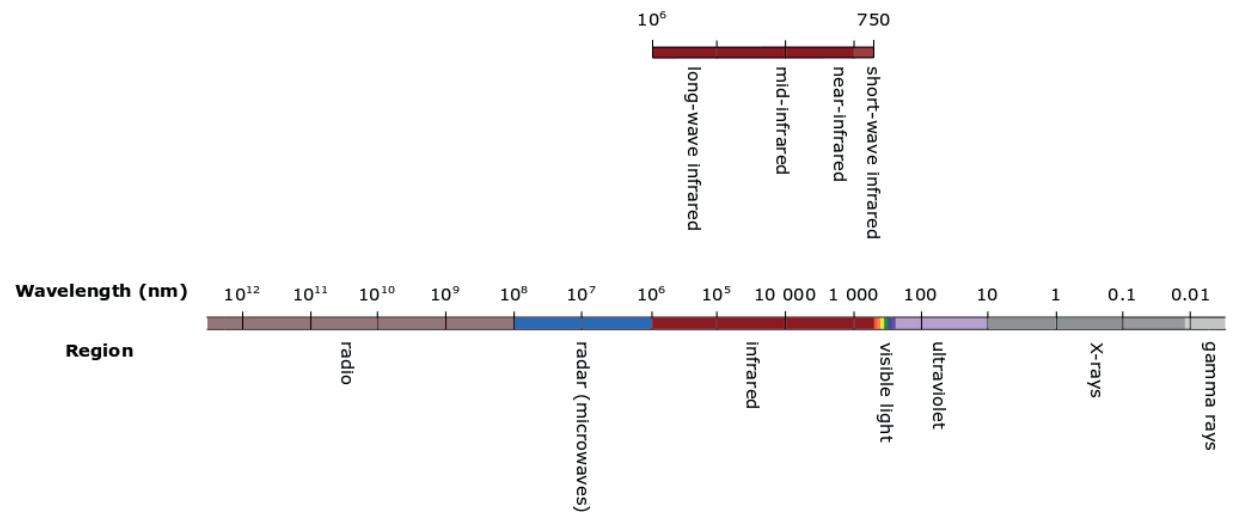

l: Electromagnetic spectrum. 
The NIR spectroscopic quantification of milk components makes use of the main region from 1100 to $2500 \mathrm{~nm}$ and relies on the component absorption overtones and combination bands (Kalinin et al., 2008; Aernouts et al., 2011). Upadhyay et al. (2018) showed that the spectral range for NIR region is from 750 to 2500 (13 400-4 $\left.000 \mathrm{~cm}^{-1}\right)$, while for MIR it is between 2500 and $25000 \mathrm{~nm}$ (4 000-400 cm-1). Tsenkova et al. (1999) describes the statistical accuracy (in terms of root mean-square error-RMSE) on the MIR spectroscopic analysis for fat content at very high complexity of PLS regression calibration models. NIR and MIR (Bogomolov and Melenteva, 2013; Feng et al., 2013) are widespread for determination milk parameters, respectively milk fat (Bogomolov et al., 2017). For example, a study by Mlček et al. (2016) reveals the determination of fat in milk using NIR which is calibrated by two routine methods (Gerber and Röse-Gottlieb). Nowadays, apparatuses based on MIR spectroscopy are the most used in industrial laboratories (e.g. MilkoScan series by Foss Electric, Denmark).

Fourier transform infrared (FTIR) spectroscopy (e.g. apparatus CombiScope FTIR series by Delta Instruments B.V., Netherlands) is rapid, easy to apply and useful for routine analysis (Wolff et al., 1998). In principal, FTIR is a biochemical fingerprinting technique (Nicolaou et al., 2010). During measurement, IR radiation is absorbed as it passes through the sample, which leads to changes in the rotational-vibrational energy states of the molecule depending on variations of the dipole moment of the molecule. This method can be applied to raw milk, drinking milk (whole, semi-skimmed and skimmed milk), cream and dairy products (yoghurt).

Also, Raman scattering, especially Fourier transform Raman (FT-Raman) spectroscopy, gives access to the vibrational fingerprints of molecules (El-Abassy et al., 2011) and similarly to FTIR, it has been demonstrated to be successful for the determination of nutritional parameters, e.g. in conjugated linoleic acids in cow 's milk fat (Meurens et al., 2005).

FTIR and attenuated total reflectance (ATR) have been used by van de Voort et al. (1992) for determination of fat and moisture contents in butter. Inon et al. (2004) used FTIR and ATR techniques with chemometric analyses (multivariate statistics) to classify drinking milks. Next, diffuse reflectance

III: Comparison of individual routine methods.

\begin{tabular}{|c|c|c|c|}
\hline Method & Principle & Use & Reference \\
\hline Turbidimetric analysis & $\begin{array}{l}\text { a measurement of intensity light passing through } \\
\text { the sample in the original direction }\end{array}$ & milk & Ashworth (1969) \\
\hline Ultrasound procedure & $\begin{array}{l}\text { a measurement of high-frequency ultrasound } \\
\text { radiation passing through the sample }\end{array}$ & milk & Perlín (2003) \\
\hline MW irradiation & $\begin{array}{l}\text { a part of the electromagnetic wave spectrum and } \\
\text { have wavelengths ranging from } 1 \mathrm{~mm} \text { to } 1 \mathrm{~m}\end{array}$ & milk & $\begin{array}{l}\text { García-Ayuso et al. } \\
\text { (1999) }\end{array}$ \\
\hline NMR & 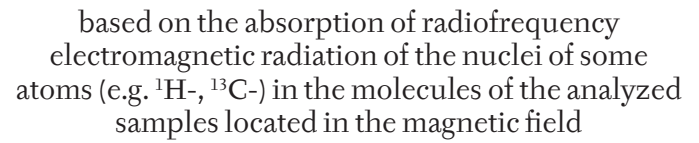 & $\begin{array}{l}\text { milk and dairy } \\
\text { products }\end{array}$ & $\begin{array}{l}\text { Belloque and } \\
\text { Ramos (1999) }\end{array}$ \\
\hline TD-NMR & $\begin{array}{l}\text { a method consist in a combined relaxation analysis } \\
\text { (the magnetization at a certain time is determined } \\
\text { by both the longitudinal (T1) and the transverse (T2) } \\
\text { NMR relaxation processes) }\end{array}$ & $\begin{array}{l}\text { milk and dairy } \\
\text { products }\end{array}$ & $\begin{array}{l}\text { Nascimento et al. } \\
\text { (2017) }\end{array}$ \\
\hline IR spectroscopy & \multicolumn{3}{|c|}{$\begin{array}{l}\text { a measurement of infrared irradiation (in near, mid etc. spectrum) absorbed or } \\
\text { reflected by sample; occur to changes in the rotational-vibrational energy states of } \\
\text { the molecule depending on variations of the dipole moment of the molecule }\end{array}$} \\
\hline FTIR & $\begin{array}{l}\text { vibrational fingerprints of molecules with integral } \\
\text { transformation (conversion of the signal from time } \\
\text { domain to frequency domain) }\end{array}$ & $\begin{array}{l}\text { milk and dairy } \\
\text { products }\end{array}$ & $\begin{array}{l}\text { Nicolaou et al. } \\
\text { (2010) }\end{array}$ \\
\hline FT-Raman & $\begin{array}{l}\text { an interaction between photons of incident light with } \\
\text { rotational-vibrational energy states of the molecule } \\
\text { (the scattered irradiation has a different wavelength } \\
\text { than the incident irradiation) }\end{array}$ & $\begin{array}{l}\text { milk and dairy } \\
\text { products }\end{array}$ & $\begin{array}{l}\text { Meurens et al. } \\
\text { (2005) }\end{array}$ \\
\hline ATR-FTIR & $\begin{array}{l}\text { a reflective technique (occur to total reflection } \\
\text { of the IR beam from modified prism-diamond, } \\
\text { germanium etc.) }\end{array}$ & $\begin{array}{l}\text { milk; } \\
\text { butter }\end{array}$ & $\begin{array}{l}\text { Inon et al. (2004); } \\
\text { Van de Voort et al. } \\
\text { (1992) }\end{array}$ \\
\hline DRIFTS & $\begin{array}{l}\text { a reflective technique (diffuse reflection consist } \\
\text { in focusing the IR beam on a sample, mostly in } \\
\text { a powder form) }\end{array}$ & milk & Pappas et al. (2008) \\
\hline
\end{tabular}

MW-microwave; NMR-nuclear magnetic resonance; TD-time-domain; IR-infrared; FT-Fourier transform; ATR-attenuated total reflectance; DRIFTS-diffuse reflectance Fourier transform infrared spectroscopy; 
Fourier transform infrared spectroscopy (DRIFTS) has been applied to distinguish sheep milk from goat milk (Pappas et al.2008).In principle, diffuse reflection consist in focusing the IR beam on a sample. The diffuse scattered irradiation is converted by a suitable optical device to the spectroscope detector (Machovič and Novák, 1998).

In general and according to the results of other authors (Tsenkova et al., 1999; Kukačková et al., 2000; Jankovská and Šustová, 2003; Hanuš et al., 2009, 2014; Mlček et al., 2016), the reliability of fat contents in raw milk (in terms of the gradual decreasing of individual differences (variability) in standard deviation value between routine and reference method results) by routine methods (in practical use under the conditions of their today technical design) is growing in the following order: IR spectroscopy with filter technology and in mid-range of spectrum = IR spectroscopy with whole spectrum and FT in mid-range of spectrum $>$ IR spectroscopy in the near-range spectrum $\geq$ turbidimetric method $>$ ultrasound method. The reliability order is also given by a growing correlation between coefficients of routine and reference results of milk fat in the same sources.

Microwave (MW) irradiation is the next method used for determination of fat. This method is used to accelerate hydrolysis of the matrix and extraction step of milk lipids (García-Ayuso et al., 1999). MW irradiation have been developed as an alternative to conventional Soxhlet extraction (García-Ayuso and de Castro, 1999). Despite this, the method has quantitative results similar to the Weibull-Berntrop extraction procedure but with lesser chemical transformation of triglycerides. However, MW irradiation is not used much for fat determination. Garber and Thole (2015) used this method for buffered dilute non-fat milk sample.

Nuclear magnetic resonance (NMR) spectroscopy provides unique qualitative and quantitative information regarding the physical properties (e.g. crystallization, thermal properties) of milk fat (Belloque and Ramos, 1999). Also, the structural characteristics (e.g. binding, spatial distance) can be determined using NMR spectroscopy. The method can be applied to raw milk, drinking milk (whole, semi-skimmed and skimmed milk), cheese, and ice cream.

Time-domain (TD)-NMR spectroscopy has been an alternative technique for fat analysis (Castell-Palou et al., 2013; Pereira et al., 2015). Compared with lipid extraction or NIR spectroscopy methods, TD-NMR has certain benefits. TD-NMR is rapid, non-invasive and provides analysis of the bulk milk composition (Nascimento et al., 2017).

In conclusion, routine methods (Tab. III) perform analyses using routine instrumental techniques for faster and less accurate results. Utilizing routine methods, a large of number of samples can be analysed. However, the disadvantages are the high acquisition cost of the apparatus equipment and the necessity of verification.

\section{CONCLUSION}

Nowadays, routine methods are an integral part for checking the quality of milk and dairy products. However, reference methods are also very important in terms of detailed description and verification. Reference method results are used regularly in individual milk laboratories and laboratory network, not only for routine method calibration purposes but also for estimation of combined enlarged uncertainties of measurement results by routine methods. Compared to routine methods, reference methods have the disadvantage of being limited in the number of determined samples. In the future, due to continuous development and improvement, routine methods will be used more often.

\section{Acknowledgments}

Supported by the Ministry of Agriculture of the Czech Republic, project No. QJ1510336 and the Grant Agency of University of South Bohemia, project No. 002/2016/Z. Authors thank to native English speaker for language improvements.

\section{REFERENCES}

AERNOUTS, B., POLSHIN, E., LAMMERTYN, J. et al. 2011. Visible and near-infrared spectroscopic analysis of raw milk for cow health monitoring: reflectance or transmittance? J. Dairy Sci., 94(11): 5315-5329.

ASHWORTH, U.S. 1969. Turbidimetric Methods for Measuring Fat Content of Homogenized Milk. J. Dairy Sci., 52(2): 262-263.

ASTAIRE, J. C., WARD, R., GERMAN, J. B. et al. 2003. Concentration of polar MFGM lipids from buttermilk by microfiltration and supercritical fluid extraction. J. Dairy Sci., 86(7): 2297-2307.

BELLOQUE, J. and RAMOS, M. 1999. Application of NMR spectroscopy to milk and dairy products. Trends Food Sci. Technol., 10(10): 313-320.

BLIGH, E. G. and DYER, W. J. 1959. A rapid method of total lipid extraction and purification. Can. J. Biochem. Physiol., 37(8): 911-917.

BOGOMOLOV, A. and MELENTEVA, A. 2013. Scatter-based quantitative spectroscopic analysis of milk fat and total protein in the region $400-1100 \mathrm{~nm}$ in the presence of fat globule size variability. Chem. Intelligent Lab. Syst., 126: 129-139. 
BOGOMOLOV, A., BELIKOVA, V., GALYANIN, V. et al. 2017. Reference-free spectroscopic determination of fat and protein in milk in the visible and near infrared region below $1000 \mathrm{~nm}$ using spatially resolved diffuse reflectance fiber probe. Talanta, 167: 563-572.

BOGOMOLOV, A., MELENTEVA, A. and DAHM, D. J. 2013. Fat Globule Size Effect on Visible and Shortwave near Infrared Spectra of Milk. J. Near Infrared Spectr., 21(5): 435-440.

BUDGE, S. M., IVERSON, S. J. and KOOPMAN, H. N. 2006. Studying the trophic ecology in marine ecosystems using fatty acids: A primer on analysis and interpretation. Mar. Mamm. Sci., 22(4): 759-801.

CABASSI, G., PROFAIZER, M., MARINONI, L. et al. 2013. Estimation of fat globule size distribution in milk using an inverse light scattering model in the near infrared region. J. Near Infrared Spectr., 21(5): 359-373.

CAES. 1894. The Babcock method of determining the proportion of fat in milk and milk products. In: Bulletin No. 117: The Babcock method of determining fat in milk and milk products. Connecticut Agricultural Experiment Station, January. New Haven, 3-11.

CASTELL-PALOU, A., ROSSELLÓ, C., FEMENIA, A. et al. 2013. Simultaneous Quantification of Fat and Water Content in Cheese by TD-NMR. Food Bioprocess Technol., 6(10): 2685-2694.

CHOI, A., FUSCH, G., ROCHOW, N. et al. 2015. Establishment of micromethods for macronutrient contents analysis in breast milk. Matern. Child Nutr., 11(4): 761-772.

CROFCHECK, C. L., PAYNE, F. A., HICKS, C. L. et al. 2000. Fiber Optic Sensor Response to Low Levels of Fat in Skim Milk. J. Food Process. Eng., 23: 163-175.

CNI. 1973. Methods for testing of milk and milk products [in Czech: Metody zkoušení mléka a tekutých mléćných výrobkĩ]. CSN 57 0530:1973. Prague: Czech Normalization Institute.

CNI. 1993. Raw cow's millk for dairy treatment and processing [in Czech: Syrové kravské mléko pro mlékárenské ošetrenenía zpracování]. CSN 57 0529:1993. Prague: Czech Normalization Institute.

CNI. 1999. Determination of milk composition by mid-infrared analyzer [in Czech: Stanovení složení mléka infračerveným absorpčním analyzátorem]. CSN 57 0536:1999. Prague: Czech Normalization Institute.

CNI. 2005. Conformity assessment - General requirements for the competence of testing and calibration laboratories [in Czech: Posuzování shody - Všeobecné požadavky na zpuisobilost zkušebních a kalibračních laboratoři C. CSN EN ISO/ IEC 17025:2005. Prague: Czech Normalization Institute.

COSMT. 2001. Milk - Determination of fat content (Routine method) [in Czech: Mléko - Stanovení obsahu tuku (Rutinní metoda)]. CSN ISO 2446:2001. Prague: Czech Office for Standards, Metrology and Testing.

COSMT. 2009. Milk and milk products - Guidance on sampling [in Czech: Mléko a mléčné výrobky - Smèrnice pro odbèr vzorkỉ]. CSN ISO 707 (57 0003). Prague: Czech Office for Standards, Metrology and Testing.

COSMT. 2011. Milk - Determination of fat content - Gravimetric method (Reference method) [in Czech: Mléko - Stanovení obsahu tuku - Vážková metoda (Referenční metoda)]. CSN EN ISO 1211:2011 (57 0534). Prague: Czech Office for Standards, Metrology and Testing.

EL-ABASSY, R. M., ERAVUCHIRA, P. J., DONFACK, P. et al. 2011. Fast determination of milk fat content using Raman spectroscopy. Vib. Spectrosc., 56(1): 3-8.

ELLER, F. and KING, J. 1996. Determination of fat content in foods by analytical SFE. Seminars Food Anal., 1: 145-162.

FENG, X.-D., SU, R., XU, N. et al. 2013. Portable analyzer for rapid analysis of total protein, fat and lactose contents in raw milk measured by non-dispersive shortwave near-infrared spectrometry. Chem. Res. Chinese Univ., 2013, 29(1): 15-19.

FOLCH, J., LEES, M. and SLOANE STANLEY, G. H. 1957. A simple method for the isolation and purification of total lipides from animal tissues. J. Biol. Chem., 226(1): 497-509.

GARBER, E. A. E. and THOLE, J. 2015. Application of Microwave Irradiation and Heat to Improve Gliadin Detection and Ricin ELISA Throughput with Food Samples. Toxins, 7(6): 2135-2144.

GARCIAA-AYUSO, L. E., and DE CASTRO, M. D. L. 1999. A multivariate study of the performance of a microwave-assisted Soxhlet extractor for olive seeds. Anal. Chim. Acta, 382(3): 309-316.

GARCÍA-AYUSO, L. E., VELASCO, J., DOBARGANES, M. C. et al. 1999. Double use of focused microwave irradiation for accelerated matrix hydrolysis and lipid extraction in milk samples. Int. Dairy J., 9(10): 667-674.

GARGIS, A. S., KALMAN, L., BERRY, M. W. et al. 2012. Assuring the quality of next generation sequencing in clinical laboratory practice. Nat. Biotech., 30(11): 1033-1036.

GERBER, N. 1891. Neuer Butyrometer. CH Patent 2621. Swiss Federal Institute of Intellectual Property.

GLANZMANN, B., GERMANN, U. and COSSU, C. 2017. Experiences in organising of proficiency tests since six years. For. Sci.Int. Gen. Suppl. Series, 6: 332-334.

GRAPPIN, R. 1987. Definition and evaluation of the overall accuracy of indirect methods of milk analysis - application to calibration procedure and quality control in dairy laboratory. Bullet. of IDF, Doc. 208, IDF Provisional Standard 128, 3-122.

GRAPPIN, R. 1993. European network of dairy laboratories. In: Proceedings of an International Analytical Quality Assurance and Good Laboratory Practice in Dairy Laboratories. Sonthofen, 18-20 May 1992. Brussels: International Dairy Federation, pp 205-211. 
HANUŠ, O., BENDA, P., JEDELSKÁ, R. et al. 1998. Design and evaluation of the first national qualitative testing of routine milk analyses. Acta Univ. Agric. Silvic. Mendelianae Brun., 46(3): 33-53.

HANUŠ, O., GENČUROVÁ, V., YONG, T. et al. 2009. Reference and indirect instrumental determination of basic milk composition and somatic cell count in various species of mammals. Sci. Agricult. Bohem., 40(4): 196-203.

HANUŠ, O., ŘÍHA, J., SAMKOVÁ, E. et al. 2014. A comparison of result reliability for investigation of milk composition by alternative analytical methods in Czech Republic. Acta Univ. Agric. Silvic. Mendelianae Brun., 62(5): 929-937

HANUŠ, O., VEGRICHT, J., FRELICH, J. et al. 2008. Analyse of raw cow milk quality according to free fatty acids contents in the Czech Republic. Czech J. Anim. Sci., 53(1): 17-30.

INON, F. A., GARRIGUES, S. and GUARDIA, M. 2004. Nutritional parameters of commercially available milk samples by FTIR and chemometric techniques. Anal. Chim. Acta, 513(2): 401-412.

ISO. 1976. Milk-determination of fat content (Butyrometric routine method). ISO 2446:1976. Geneva: International Standards Office.

ISO. 2005. Milk products and milk-based foods-determination of fat content by the Weibull-Berntrop gravimetric method (Reference method) - Part 1: Infant foods. ISO 8262-1:2005. Geneva: International Standards Office.

ISO. 2005. Milk products and milk-based foods-determination of fat content by the Weibull-Berntrop gravimetric method (Reference method) - Part 2: Edible ices and ice-mixes. ISO 8262-2:2005. Geneva: International Standards Office.

ISO. 2005. Milk products and milk-based foods-determination of fat content by the Weibull-Berntrop gravimetric method (Reference method) - Part 3: Special cases. ISO 8262-3:2005. Geneva: International Standards Office.

ISO. 2010. Conformity assessment-general requirements for proficiency testing. ISO 17043:2010. Geneva: International Standards Office.

IVERSON, S. J., LANG, S. L. C. and COOPER, M. H. 2001. Comparison of the Bligh and Dyer and Folch methods for total lipid determination in a broad range of marine tissue. Lipids, 36(11): 1283-1287.

JANKOVSKÁ, R. and ŠUSTOVÁ, K. 2003. Analysis of cow milk by near-infrared spectroscopy. Czech J. Food Sci., 21(4): 123-128.

JENSEN, R. G. and NEWBURG, D. S. 1995. Bovine milk lipids. In: JENSEN, R. G. (Ed.). Handbook of Milk Composition. 1st edition. London: Academic Press, pp. 543-575.

KAARLS, R., MACKAY, L., SAMUEL, A. et al. 2017. Laboratory capacity building through the use of metrologically traceable reference values in proficiency testing programmes. Accred. Qual. Assur., 22(6): 321-334.

KALININ, A., KRIVTSUN, V., KRASHENINNIKOV, V. et al. 2008. Calibration models for multi-component quantitative analyses of dairy with the use of two different types of portable near infrared spectrometer. J. Near Infrared Spectr., 16(3): 343-348.

KESSLER, R. W. 2013. Perspectives in process analysis. J. Chemometrics, 27(11): 369-378.

KLEYN, D. H., TROUT, J. R. and WEBER, M. 1988. Determination of fat in raw milk: comparison of mojonnier (ether extraction) and Gerber method. J. Assoc. Off. Anal. Chem., 1988, 71(4): 851-853.

KUCHERYAVSKIY, S., MELENTEVA, A. and BOGOMOLOV, A. 2014. Determination of fat and total protein content in milk using conventional digital imaging. Talanta, 121: 144-152.

KUKAČKOVÁ, O., ČURDA, L. and JINDŘICH, J. 2000. Multivariate calibration of raw cow milk using NIR spectroscopy. Czech J. Food Sci., 18(1): 1-4.

LERAY, O. 2009a. ICAR AQA strategy - International anchorage and harmonization. In: Proceedings of the 36th ICAR Biennial Session. Niagara Falls, 16-20 June. Rome: ICAR Technical Series, pp 295-300.

LERAY, O. 2009b. Interlaboratory reference system and centralized calibration - Prerequisites and standard procedures. In: Proceedings of the 36th ICAR Biennial Session. Niagara Falls, 16-20 June. Rome: ICAR Technical Series, pp 301-305.

LERAY, O. 2010. Analytical precision performance in ICAR proficiency testing programmes. In: Proceedings of the 37th ICAR Biennial Session. Riga, 31 May - 4 June. Rome: ICAR Technical Series, pp 263-270

LIU,Z. Q., ROCHFORT, S. and COCKS, B. G. 2016. Optimization of a single phase method for lipid extraction from milk. J. Chromatogr. A, 1458: 145-149.

LOCK, A. L. and BAUMAN, D. E. 2011. Milk fat and human health - separating fats from fiction. In: Proceedings 2011 Cornell Nutrition Conference for Feed Manufacturers. Cornell University, 18-20 October. New York: Department of Animal Science, Cornell University, pp. 126-135.

MACHOVIČ, V. and NOVÁK, F. 1998. Diffuse reflectance infrared spectroscopy of soil bitumens from Sumava region [in Czech: Difuznè-reflexní infračervená spektroskopie puidních bitumenü z oblasti Šumavy]. Chem. Listy, 92(2): 151-156.

MANGANIELLO, L., RÍOS, A. and VALCÁRCEL, M. 2000. Automatic microgravimetric determination of fats in milk products by use of supercritical fluid extraction with on-line piezoelectric detection. $J$. Chromatography A, 874(2): 265-274.

MARMER, W. N. and MAXWELL, R. J. 1981. Dry Column Method for the Quantitative Extraction and Simultaneous Class Separation of Lipids from Muscle Tissue. Lipids, 16(5): 365-371. 
MAXWELL, R. J., MONDIMORE, D. and TOBIAS, J. 1986. Rapid method for the quantitative extraction and simultaneous class separation of milk lipids. J. Dairy Sci., 69(2): 321-325.

MEURENS, M., BAETEN, V., YAN, S. H. et al. 2005. Determination of the conjugated linoleic acids in cow's milk fat by Fourier transform Raman spectroscopy. J. Agri. Food Chem., 53(15): 5831-5835.

MILTON, M. J. T. and QUINN, T. J. 2001. Primary Methods for the Measurement of Amount of Substance. Metrologia, 38(4): 289-296.

MLČEK, J., DVOŘÁK, L., ŠUSTOVÁ, K. et al. 2016. Accuracy of the FT-NIR Method in Evaluating the Fat Content of Milk Using Calibration Models Developed for the Reference Methods According to RöseGottlieb and Gerber. J. AOAC Int., 99(5): 1305-1309.

NASCIMENTO, P. A. M., BARSANELLI, P. L., REBELLATO, A. P. et al. 2017. Time-Domain Nuclear Magnetic Resonance (TD-NMR) and Chemometrics for Determination of Fat Content in Commercial Products of Milk Powder. J. AOAC Int., 100(2): 330-334.

NICOLAOU, N., XU, Y. and GOODACRE, R. 2010. Fourier transform infrared spectroscopy and multivariate analysis for the detection and quantification of different milk species. J. Dairy Sci., 93(12): 5651-5660.

OFTEDAL, O. T., EISERT, R. and BARRELL, G. K. 2014. Comparison of analytical and predictive methods for water, protein, fat, sugar, and gross energy in marine mammal milk. J. Dairy Sci., 97(8): 4713-4732.

PAPPAS, C. S., TARANTILIS, P. A., MOSCHOPOULOU, E. et al. 2008. Identification and differentiation of goat and sheep milk based on diffuse reflectance infrared Fourier transform spectroscopy (DRIFTS) using cluster analysis. Food Chem., 106(3): 1271-1277.

PEREIRA, F. M. V., REBELLATO, A. P., PALLONE, J. A. L. et al. 2015. Through-package fat determination in commercial Samples of mayonnaise and salad dressing using time-domain nuclear magnetic resonance spectroscopy and chemometrics. Food Control, 48: 62-66.

PERLÍN, C. 2003. Ultrasonic milk analyzer. UZEI 15557 [in Czech: Ultrazvukový analyzátor mléka]. [Online]. Available at: http://www.agronavigator.cz/default.asp?ch=15\&typ=1\&val=15557\&ids=199. [Accessed: 2018, July 19].

QUINN, T. J. 1997. Primary methods of measurement and primary standards. Metrologia, 34(1): 61-65.

RINNAN, A., VAN DER BERG, F. W. J. and ENGELSEN, S. B. 2009. Review of the most common preprocessing techniques for near-infrared spectra. TRAC Trends Anal. Chem., 28(10): 1201-1222.

SAHENA, F., ZAIDUL, I. S. M., JINAP, S. et al. 2009. Application of supercritical $\mathrm{CO}_{2}$ in lipid extraction - A review. J. Food Eng., 95(2): 240-253.

SAMKOVÁ, E., ŠPIČKA, J., PEŠEK, M., et al. 2012. Animal factors affecting fatty acid composition of cow milk fat: A review. South Afr. J. Anim. Sci., 42(2): 83-100.

ŠPRONGL, L. and PAULIKK, M. 2011. Quality systems in the laboratory. In: BARTU゚ŇKOVÁ, J., HRUŠÁK, O., PAULÍK, M. et al. (eds). Investigative methods in imunology [in Czech: Systémy jakosti (kvality) v laboratoři. Vyšetřovací metody v imunologii]. 2nd edition. Prague: Grada Publishing, pp 149-155.

TANKIEWICZ, M. and BIZIUK, M. 2018. Fast, sensitive and reliable multi-residue method for routine determination of 34 pesticides from various chemical groups in water samples by using dispersive liquid-liquid microextraction coupled with gas chromatography-mass spectrometry. Anal. Bioanal. Chem., 410(5): 1533-1550.

TSENKOVA, R., ATANASSOVA, S., TOYODA, K. et al. 1999. Near-infrared spectroscopy for dairy management: Measurement of unhomogenized milk composition. J. Dairy Sci., 82(11): 2344-2351.

UPADHYAY, N., JAISWAL, P. and JHA, S. N. 2018. Application of attenuated total reflectance Fourier Transform Infrared spectroscopy (ATR-FTIR) in MIR range coupled with chemometrics for detection of pig body fat in pure ghee (heat clarified milk fat). J. Mol. Struc., 1153: 275-281.

VAN DE VOORT, F. R., SEDMAN, J., EMO, G. et al. 1992. A Rapid FTIR quality control method for fat and moisture determination in butter. Food Res. Int., 25(3): 193-198.

VAN DER MEER, F. 2018. Near-infrared laboratory spectroscopy of mineral chemistry: A review. Int. J. Appl. Earth Obs. Geoinf., 65: 71-78.

VERREZEN, F., VASILE, M., LOOTS, H. et al. 2017. Method validation and verification in liquid scintillation counting using the long-term uncertainty method (LTUM) on two decades of proficiency test data. J. Radioanal. Nucl. Chem., 314(2): 737-742.

VIEITEZ, I., IRIGARAY, B., CALLEJAS, N. et al. 2016. Composition of fatty acids and triglycerides in goat cheeses and study of the triglyceride composition of goat milk and cow milk blends. J. Food Comp. Anal., 48: 95-101.

WHEATLEY, K. E., BRADSHAW, C. J. A., HARCOURT, R. G. et al. 2008. Feast or famine: Evidence for mixed capital-income breeding strategies in Weddell seals. Oecologia, 155(1): 11-20.

WOLF, W. R., LACROIX, D. E., GOEL, R. et al. 2003. Total fat analysis in milk- and soy-based infant formula powder by supercritical fluid extraction. J. Am. Oil Chem. Soc., 80(9): 853-857.

WOLFF, R. L., COMBE, N. A., PRECHT, D. et al. 1998. Accurate determination of trans-18:1 isomers by capillary gas-liquid-chromatography on cyanoalkyl polysiloxane stationary phases. Oil. Fats Crops Lipids, 5(4): 295-300.

ZHU, X., GUO, W. and LIANG, Z. 2015. Determination of the Fat Content in Cow's Milk Based on Dielectric Properties. Food Bioproc. Technol., 8(7): 1485-1494. 
Robert Kala: kalaro00@zf.jcu.cz

Contact information

Eva Samková:samkova@zf.jcu.cz

Lenka Pecová: pecovl00@zf.jcu.cz

Oto Hanuš: hanus.oto@seznam.cz

Kęstutis Sekmokas: kestutis.sekmokas@pieno-tyrimai.lt

Dalia Riaukienè: dalia@pieno-tyrimai.lt 